\title{
Susceptibility-weighted MRI signs of compensatory mechanism in nonconvulsive status epilepticus
}

Figure

EEG and MRI (apparent diffusion coefficient [ADC], susceptibility-weighted imaging [SWI], arterial spin labeling [ASL]) findings before, during, and after nonconvulsive status epilepticus (NCSE)
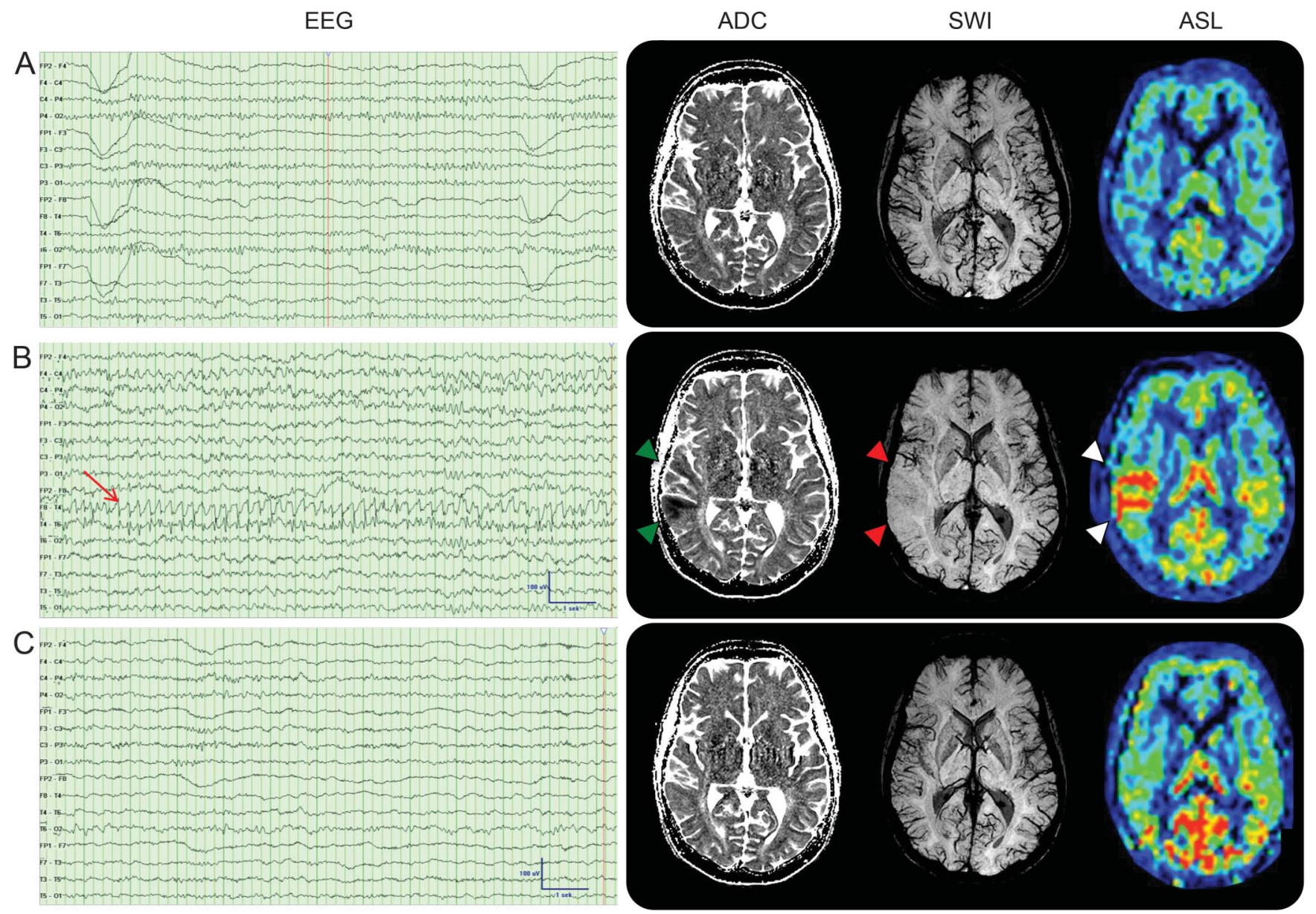

Unremarkable EEG and MRI at presentation (A); follow-up EEG (B) demonstrates right frontotemporal rhythmic epileptiform discharges (red arrow). Right temporal ADC reduction (green arrowheads) and matching areas of reduced visibility of cortical veins (red arrowheads) and hyperperfusion on ASL maps (white arrowheads). On follow-up, EEG and MRI findings normalized (C).

A 22-year-old woman was diagnosed with CSF antibody-confirmed NMDA receptor encephalitis after repeated generalized seizures. Initial MRI and EEG were unremarkable (figure). She developed acoustic hallucinations and nonconvulsive status epilepticus (NCSE). MRI at this time showed hyperperfusion on arterial spin labeling maps and reduced apparent diffusion coefficient accompanied by reduced visibility of cortical veins on susceptibility-weighted MRI. The striking correlation between EEG and MRI findings suggests focal metabolic exhaustion (low apparent diffusion coefficient) and increased demand (hyperperfusion) caused by NCSE and reduced paramagnetic effect due to increased levels of oxygenated hemoglobin resulting in reduced venous signal. ${ }^{1,2}$ All findings normalized under treatment.

Philipp Eisele, MD, * Achim Gass, MD, *Angelika Alonso, MD, Marc E. Wolf, MD, Martin Griebe, MD, Kristina Szabo, $M D$ 
*These authors contributed equally to this work.

From the Department of Neurology, Universitätsmedizin Mannheim, University of Heidelberg, Mannheim, Germany.

Author contributions: Philipp Eisele, MD: drafting and revising the manuscript, clinical care of patient, interpretation and preparation of images. Achim Gass, MD: acquisition, interpretation and preparation of images, drafting and revising the manuscript. Angelika Alonso, MD: clinical care of patient, interpretation and preparation of images, revising the manuscript. Marc Wolf, MD: acquisition, interpretation, and preparation of images, revising the manuscript. Martin Griebe, MD: acquisition, interpretation and preparation of images, revising the manuscript. Kristina Szabo; MD: drafting and revising the manuscript, clinical care of patient, acquisition, interpretation, and preparation of images.

Study funding: No targeted funding reported.

Disclosure: P. Eisele has received travel expenses from Bayer Health Care. A. Gass has received honoraria for lecturing, travel expenses for attending meetings, and financial support for research from Bayer Schering, Biogen Idec, Merck Serono, Novartis, and TEVA

Neurosciences. A. Alonso is on the editorial board for Advances in Neuroscience and Cerebrovascular Diseases. M. Wolf reports honoraria for lecture from Biogen Idec. M. Griebe reports honoraria for lecture from Biogen Idec and travel and lecture expenses from Bayer Health Care. K. Szabo serves on the editorial board for Cerebrovascular Diseases and has received research support from the German Research Foundation (DFG). Go to Neurology.org for full disclosures.

Correspondence to Dr. Eisele: eisele@neuro.ma.uni-heidelberg.de

1. Aellen J, Abela E, Buerki SE, et al. Focal hemodynamic patterns of status epilepticus detected by susceptibility weighted imaging (SWI). Eur Radiol 2014;24:2980-2988.

2. Sedlacik J, Kutschbach C, Rauscher A, Deistung A, Reichenbach JR. Investigation of the influence of carbon dioxide concentrations on cerebral physiology by susceptibility-weighted magnetic resonance imaging (SWI). Neuroimage 2008;43:36-43.

\section{Get Connected. Stay Connected.}

Connect with the American Academy of Neurology's popular social media channels to stay up-todate on the latest news and breakthroughs in neurology, and network with peers and neurology thought leaders. Visit $A A N$.com/Connect.

\section{Neurology ${ }^{\circledR}$ Resident \& Fellow Section now Recruiting New Editorial Team Members!}

The Neurology Resident and Fellow Editorial team is seeking neurology resident to serve a three-year term as Editorial team members for the Neurology Resident and Fellow Section.

Apply by July 15, 2016 neurology.org/site/feature/recruit.xhtml

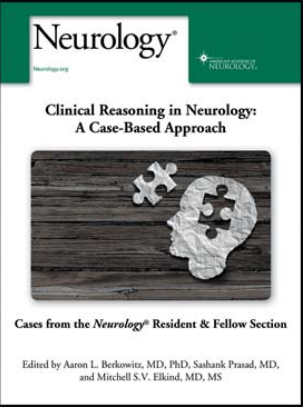

\section{Program Directors \& Trainees!}

FREE Download of R\&F Book:

Clinical Reasoning in Neurology

The new Clinical Reasoning Book edited by Aaron Berkowitz, Sashank Prasad, and Mitchell Elkind is available as a FREE pdf download or on the Neurology app for the iPad and Android Devices.

http://www.neurology.org/site/feature/clinicalreasoningbook.xhtml 


\section{Neurology}

\section{Susceptibility-weighted MRI signs of compensatory mechanism in nonconvulsive status epilepticus}

Philipp Eisele, Achim Gass, Angelika Alonso, et al. Neurology 2016;87;116-117

DOI 10.1212/WNL.0000000000002815

\section{This information is current as of July 4, 2016}

\section{Updated Information \& Services}

\section{References}

Subspecialty Collections

Permissions \& Licensing

Reprints including high resolution figures, can be found at: http://n.neurology.org/content/87/1/116.full

This article cites 2 articles, 0 of which you can access for free at: http://n.neurology.org/content/87/1/116.full\#ref-list-1

This article, along with others on similar topics, appears in the following collection(s):

\section{DWI}

http://n.neurology.org/cgi/collection/dwi

EEG

http://n.neurology.org/cgi/collection/eeg MRI

http://n.neurology.org/cgi/collection/mri

Status epilepticus

http://n.neurology.org/cgi/collection/status_epilepticus

Information about reproducing this article in parts (figures,tables) or in its entirety can be found online at:

http://www.neurology.org/about/about_the_journal\#permissions

Information about ordering reprints can be found online:

http://n.neurology.org/subscribers/advertise

Neurology ${ }^{\circledR}$ is the official journal of the American Academy of Neurology. Published continuously since 1951, it is now a weekly with 48 issues per year. Copyright @ 2016 American Academy of Neurology. All rights reserved. Print ISSN: 0028-3878. Online ISSN: 1526-632X.

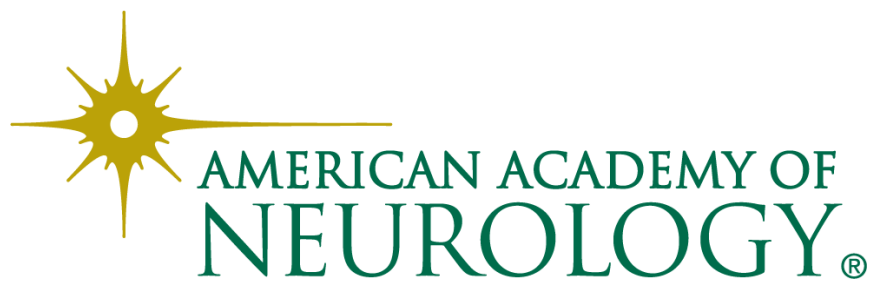

